\title{
PERILAKU PEMENUHAN GIZI PADA IBU MENYUSUI DI BEBERAPA ETNIK DI INDONESIA
}

\section{Nutrition Fulfillment Behaviors in Breastfeeding Mothers in Several Ethnicities in Indonesia}

\author{
Oktarina, Yurika Fauzia \\ UPF Inovasi Teknologi Kesehatan, Puslitbang Humaniora dan Manajemen Kesehatan \\ Naskah masuk: 18 Maret 2019 Perbaikan: 21 Mei 2019 Layak terbit: 5 November 2019 \\ https://doi.org/10.22435/hsr.v22i4.1550
}

\begin{abstract}
ABSTRAK
Gizi seimbang penting bagi ibu menyusui karena sangat erat kaitannya dengan produksi air susu. Pemenuhan gizi yang baik akan berpengaruh terhadap status gizi ibu menyusui dan tumbuh kembang bayinya. Konsep tentang sehat-sakit, makanan-minuman yang baik untuk kesehatan, kepercayaan dan pantangan, di satu lain bisa menjadi penghalang namun di sisi lain bisa menjadi potensi untuk mengatasi permasalahan kesehatan. Penelitian ini merupakan analisis data sekunder, yang bersumber dari data Riset Etnografi Kesehatan tahun 2012, 2014 dan 2015 yang bertujuan untuk mengetahui perilaku pemenuhan gizi ibu menyusui pada etnik Sabu, Rote dan Madura. Data yang dikumpulkan meliputi perilaku ibu menyusui serta kecukupan zat gizi ibu menyusui pada tiga etnik tersebut. Hasil menunjukkan bahwa perilaku ibu pada bayi baru lahir memberikan jenis makanan prelaktal, dimana pada etnik Rote berupa air kopi atau air gula, pada etnik Sabu berupa ramuan daun cabai yang ditumbuk, disaring dan diambil sarinya, serta etnik Madura berupa madu dan air kelapa muda yang bertujuan untuk melicinkan pencernaan bayi.
\end{abstract}

Kata kunci: Perilaku Ibu menyusui, Etnik Rote, Etnik Sabu dan Etnik Madura

\begin{abstract}
Balanced nutrition during breastfeeding is important for breastfeeding mothers because it affects breastmilk production. The fulfillment of good nutrition for breastfeeding mothers will affect the nutritional status and the growth of their babies. The concept of sick and healthy, food and drink that is good for health, trust and abstinence, on one hand, can be a barrier for health development but on the other one can be a potential for overcoming health problems. This study is a secondary data analysis, which is sourced from Health Ethnographic Research data in 2012, 2014 and 2015. Samples taken were from the Rote, Sabu and Madura ethnic groups. Data collected included breastfeeding mothers' behavior as well as the adequacy of nutrition for breastfeeding mothers in the three ethnic groups. The results showed that maternal behavior in newborns gave a prelactal type of food, where in the ethnic Rote in the form of coffee water or sugar water, in the ethnic Sabu in the form of a concoction of chili leaves that were pounded, filtered and taken the juice, and the Madura ethnic in the form of honey and young coconut water aimed to smoothen baby's digestion.
\end{abstract}

Keywords: The behavior of nursing mothers, Rote Ethnic, Sabu Ethnic and Ethnic Madurese

\section{PENDAHULUAN}

Adat istiadat dan perilaku masyarakat di satu sisi merupakan hal yang menunjang kehidupan sosial masyarakat, karena polanya yang didasarkan atas kebiasaan yang ada pada masyarakat setempat. Pada sisi lainnya, terkadang adat istiadat menjadi penghalang atau penghambat terciptanya pola hidup sehat di masyarakat. Perilaku, kebiasaan, dan adat istiadat yang merupakan penghambat misalnya; ibu menyusui dilarang makan makanan yang asin, seperti ikan asin, telur asin karena bisa membuat air susu ibu (ASI) jadi asin (Firman Edu, 2015).

Korespondensi:

Oktarina

UPF Inovasi Teknologi Kesehatan

E-mail: oktarina131064@yahoo.com 
Makanan merupakan kebutuhan dasar manusia. Kecukupan makanan yang tepat dan bervariasi dapat menciptakan kesehatan yang optimal. Kecukupan gizi akan memberikan pengaruh pada kualitas dan kuantitas ASI yang akan dihasilkan oleh seorang ibu menyusui. Seseorang yang mempunyai kemungkinan lebih besar untuk dapat menghasilkan air susu dalam jumlah maksimal, maka diperkirakan kandungan zat gizi yang terdapat dalam air susu juga mencukupi (Arisman M.B, 2007).

Menyusui merupakan cara alamiah untuk memberikan makanan dan minuman pada awal kehidupan bayi. Kebutuhan gizi ibu perlu diperhatikan pada masa menyusui karena gizi yang masuk tidak hanya harus mencukupi kebutuhan dirinya melainkan harus memproduksi ASI bagi bayinya (Kemenkes RI, 2014). Beberapa manfaat ASI bagi bayi yaitu menurunkan risiko kematian bayi akibat diare dan infeksi, mengurangi angka kematian di kalangan anak-anak yang kekurangan gizi, perlindungan terhadap infeksi gastrointestinal, serta sumber energi dan nutrisi bagi bayi usia 6 sampai 23 bulan. Sedangkan manfaat bagi ibu yang memberikan ASI adalah mengurangi risiko kanker ovarium dan payudara, membantu kelancaran produksi ASI, sebagai metode alami pencegahan kehamilan dalam enam bulan pertama setelah kelahiran, dan membantu mengurangi berat badan lebih dengan cepat setelah kehamilan (WHO, 2016). Cakupan pemberian ASI eksklusif di Indonesia sebesar 54,3\%, dimana persentase tertinggi terdapat di Provinsi NTB sebesar $79,7 \%$ dan terendah di Provinsi Maluku sebesar 25,2\% (Riskesdas, 2013).

Makanan/minuman prelakteal adalah makanan/ minuman yang diberikan pada bayi satu sampai tiga hari setelah lahir sebelum ASI keluar (Anur Rohmin, 2015). Faktor yang banyak menggagalkan praktek ASI eksklusif diantaranya makanan/minuman prelakteal. Jenis makanan/minuman prelakteal diberikan kepada bayi baru lahir di Indonesia sebagian besar berupa susu formula $(79,8 \%)$, madu/madu +air $(47,5 \%)$, air putih $(45,3 \%)$, air gula $(23,8 \%)$, pisang dihaluskan $(14,0)$, nasi dihaluskan $(10,8 \%)$, air + kopi $(9,0 \%)$, susu non formula (7,1\%) (Riskesdas, 2013). Informasi perilaku pemberian makanan prelakteal pada bayi baru lahir terdapat pada beberapa studi etnografi kesehatan ada pada beberapa etnik di Indonesia yaitu pada etnik Madura, etnik Rote, dan etnik Sabu (Ratna W, 2012, Marizka, 2014, Roland A.N, 2015) sehingga dapat diungkap perilaku pemberian makanan prelakteal tersebut secara budaya.

\section{METODE}

Penelitian ini menggunakan data sekunder yang bersumber dari data Riset Etnografi Kesehatan tahun 2012, 2014, 2015 dengan mengambil lokasi di tiga Kabupaten di Provinsi NTT dan Provinsi Jawa Timur dengan angka kematian bayi (infant mortality) diatas rata-rata nasional yaitu 35\% (SDKI, 2007). Sampel yang diambil berasal dari etnik Rote, etnik Sabu dan etnik Madura. Data yang dianalisis meliputi perilaku ibu menyusui, pemberian ASI eksklusif, frekuensi pemberian ASI serta kecukupan zat gizi ibu menyusui pada tiga etnik tersebut.

\section{HASIL}

\section{Perilaku Ibu Menyusui}

Perilaku menyusui etnik Rote khususnya di Desa Limakoli, secara turun temurun. Pada saat hendak menyusui, seorang ibu mengaku tidak mempunyai kebiasaan mencuci tangannya terlebih dahulu. Kebanyakan para ibu mengatakan ASI baru keluar dengan lancar tiga hari setelah melahirkan. Mereka juga menggunakan ramuan untuk memperlancar ASI, selain mengkonsumsi makanan tersebut. Untuk memperlancar ASI, para ibu di Desa Limakoli mengkonsumsi kacang hijau, daging ayam dan daging sapi. Daging ayam atau daging sapi diolah dengan cara di goreng, direbus atau dipanggang dan di masak tanpa menggunakan bumbu, hanya garam saja. Mereka juga menggunakan ramuan untuk memperlancar ASI, selain mengkonsumsi makanan tersebut. Ramuan yang digunakan adalah minyak kelapa dicampur tumbukan buah kelapa yang sudah dijemur dan dibakar kemudian dengan menambahkan air lalu di pijat pada bagian payudara dan punggung ibu setiap pagi selama tiga hari berturut-turut.

Perilaku masyarakat etnik Sabu di Desa Kolorae Kecamatan Raijua juga jauh dari kebiasaan sehat. Semua aktivitas mencuci tangan dengan sabun tidak pernah terlihat, bahkan setelah menceboki bayi mereka tidak mencuci tangan dengan sabun lalu langsung dan menyusui bayinya. Masyarakat etnik Sabu sudah diajarkan oleh orang tua mereka serta oleh Banni Deo (dukun bayi) secara turun temurun mengenai kebiasaan pemberian ramuan daun cabai/lombok atau disebut "Ro'Hili yang ditumbuk dan diambil sarinya. Air gula sabu diberikan dengan menggunakan jari yang dimasukkan ke dalam mulut bayi. Air gula sabu/gula lontar ini juga dikonsumsi sebagai makanan pokok untuk keluarga mulai orang tua sampai bayi baru lahir. Untuk bayi, air gula sabu 
diberikan secara bergantian dengan ASI apabila ASI sudah keluar. Air gula sabu dan ASI ini diberikan untuk bayi sampai berusia satu tahun dan tidak ada makanan yang lain (Roland A.N, dkk, 2015).

Bagi etnik Madura perilaku ibu menyusui baru pertama kali melahirkan dan belum pernah menyusui sebelumnya, diajarkan oleh orang tuanya. Caranya ibu duduk di kursi dan di pangkuannya diletakkan sebuah bantal, kemudian bayi didekap di atas bantal, lalu mulut bayi diarahkan ke puting susu ibu. Bantal yang ada di pangkuan ibu memudahkan mulut bayi menggapai puting ibu. Apabila bayi sedang berada di tempat tidur, maka cara menyusuinya, ibu memiringkan posisi tubuhnya menghadap bayi dan meletakkan puting susu ke mulut bayi. Posisi yang lain adalah ibu berdiri sambil menggendong bayi dengan menggunakan gendongan, lalu bayi dimiringkan menghadap dada ibu sehingga bisa langsung disusui (Ratna W, dkk, 2012).

Perilaku ibu untuk memperlancar ASI pada etnik Madura ini dengan membuat ramuan yang disebut pejje yaitu air hangat hasil rendaman abu bekas pembakaran tungku, abu biasa (tanah), dan asam jawa. Ramuan ini dioleskan di payudara dan diyakini bisa memperlancar ASI. Selain itu ibu yang menyusui dan ibu nifas yang mengonsumsi jamu terbuat dari daun-daunan, biji-bijian dan akar kayu yang disebut jamu galohgor. Ibu menyusui juga mengonsumsi jamu gendong yang di percaya bermanfaat untuk meningkatkan produksi ASI, kebugaran tubuh dan pemulihan Rahim (Dahlianti, Nasoetion and Roosita, 2005).

\section{Pemberian ASI Eksklusif}

Pada PP No 33 tahun 2012 tentang pemberian ASI eksklusif pasal 1 ayat 2 berbunyi ASI eksklusif diberikan kepada bayi sejak dilahirkan selama 6 bulan, tanpa menambah dan atau mengganti dengan makanan atau minuman lain. ASI eksklusif adalah pemberian ASI yang dilakukan sedini mungkin setelah persalinan, tanpa jadwal dan tidak diberikan makanan lain, walaupun air putih sampai bayi berusia 6 bulan (Rukiyah, dkk., 2010). Menurut WHO (2013), ASI eksklusif adalah pemberian ASI secara eksklusif pada bayi hanya diberikan ASI saja sampai usia enam bulan tanpa tambahan cairan lain seperti susu formula, jeruk, madu, air putih, air teh, air kopi, dan tanpa tambahan makanan padat seperti pisang, pepaya, bubur susu, biskuit, bubur nasi dan nasi tim kecuali larutan rehidrasi oral atau vitamin drop atau tetes, mineral atau obat-obatan.
Pada etnik Rote bila ASI belum keluar, bayi akan diberikan susu formula atau air teh. Pengertian dan manfaat kolostrum atau air susu yang pertama kali keluar, tidak diketahui oleh para ibu di Desa Limokali. Kolostrum dianggap air susu yang lebih kental. Meskipun sebagian ibu sudah mendengar informasi mengenai ASI eksklusif dari petugas kesehatan di Posyandu, tetapi masih terdapat masyarakat yang kurang memahami.

Masyarakat etnik Sabu sebagian besar para ibu belum memahami pengertian ASI ekslusif dengan baik karena dalam pelaksanaannya pada bayi dibawah enam bulan pemberian ASI masih diselingi dengan gula sabu. Sayangnya data pemberian ASI eksklusif di etnik Sabu tidak ada. Jenis makanan prelakteal yang diberikan pada bayi selain air gula sabu yang rasanya manis, juga diberikan susu kambing yang di campur gula sabu dan susu formula dimasukkan dalam botol. Sebagian besar para ibu bayi dan balita di Desa Kolorae memberikan minuman gula sabu sehari tiga kali pada bayi dan balitanya.

Pada etnik Madura pemberian madu dan kelapa muda kepada bayi baru lahir menurut keyakinan masyarakat setempat bertujuan untuk melicinkan pencernaan bayi sehingga dapat menerima jenis makanan apa pun. Ibu yang melahirkan di polindes akan langsung dibimbing oleh bidan untuk Inisiasi Menyusui Dini (IMD) sehingga ASI yang pertama kali keluar (kolostrum) diberikan kepada bayi. Namun terkadang bidan tidak mendampingi IMD secara sempurna sehingga ketika bayi sudah berada di atas dada ibu untuk mencari putting ibu, bidan sudah menggendong bayi kembali sebelum bayi berhasil menyusu ASI. Beberapa ibu masih ada yang membuang kolostrum dengan alasan kolostrum adalah ASI yang kotor. Ada ibu yang sudah menyadari bahwa kolostrum baik untuk bayi dan memberikannya.

\section{Pemberian Minuman Bayi Baru Lahir Sebelum ASI}

Kebiasaan yang tidak mendukung upaya pemberian ASI secara eksklusif berpengaruh buruk terhadap kesehatan bayi baru lahir. Kebiasaan tersebut adalah pemberian minuman pertama kepada bayi berupa air kopi atau air gula sebelum ASI keluar atau prelakteal (Hamzah, Asiah, 2000). Perilaku ibu etnik Rote di Desa Limakoli dalam pemberian seduhan air kopi atau air gula pada bayi baru lahir ini dipercaya bisa memperkuat dada bayi, bayi menjadi kuat dan tidak mudah sakit. Pemberian 
air kopi atau air gula ini sebanyak tiga sendok teh dan diberikan hanya sekali sesaat setelah bayi lahir. Tradisi pemberian minuman ini sudah dilakukan sejak zaman nenek moyang secara turun menurun dan masih bertahan sampai sekarang. Meskipun ASI eksklusif tidak terpenuhi karena pemberian air kopi, di Desa Limakoli bayi diberikan ASI rata-rata sampai usia bayi 6 bulan dan tanpa makanan apapun. Setelah usia enam bulan, mereka tetap meneruskan pemberian ASI sampai usia satu atau satu setengah tahun. Menurut informan masa menyusui merupakan masa penting dalam pertumbuhan bayi (Marizka K, dkk, 2014).

Berbeda dengan ibu etnik Sabu di Desa Kolorae. Di daerah tersebut, bayi yang baru lahir diberi ramuan daun cabe/Lombok atau "Ro Hili". Daun tersebut ditumbuk dan diambil air sarinya dengan cara disaring dan diberikan kepada bayi sebelum bayi diberi gula sabu. Air daun Lombok ini dipercaya untuk membersihkan pencernaan bayi untuk mengeluarkan lendir agar perut bayi bersih dari cairan ketuban yang tertelan saat proses persalinan. Menurut keterangan informan "supaya ana mea/bayi dan mengeluarkan lendir dan kotoran sampai bersih, sehingga perut bayi tidak kembung, kasi minum bayi, pagi, siang dan malam hari sebelum air susu ibu keluar.." (HK, 65 tahun).

Etnik Sabu lainnya, yaitu di Pulau Rajua berbeda lagi kebiasaannya. Di daerah tersebut air gula sabu diberikan sebelum keluar ASI saat selesai persalinan berguna buat bayi karena rasa manisnya disukai bayi sebagai penggantinya ASI.

Pada etnik Madura bayi mulai diperkenalkan minuman selain ASI beberapa jam setelah lahir, di antaranya madu dan kelapa muda. Bayi disuapi madu beberapa tetes dengan menggunakan jari telunjuk neneknya yang belum cuci tangan. Siapa pun bisa menyuapi madu ini, tidak harus si ibu. Tiga jam kemudian, bayi disuapi ro'-moro' (kelapa muda) sekitar 2-3 sendok oleh ibunya. Ibu pun mengonsumsi kelapa muda setelah menyuapi bayinya. Menurut keyakinan masyarakat setempat, madu dan kelapa muda bermanfaat untuk melicinkan pencernaan bayi sehingga dapat menerima makanan apa pun yang diberikan kepadanya (Ratna W, dkk, 2012).

\section{Pemberian Makanan Pendamping ASI}

Perilaku ibu dalam memberikan makanan pendamping ASI pada etnik Rote di Desa Limakoli pada usia bayi usia enam bulan ke atas. Makanan pendamping ASI berupa bubur nasi atau bubur dari beras yang dibuat sendiri oleh ibu, juga bubur instan. Sedangkan pada etnik Sabu, beberapa bayi berhenti minum ASI sebelum usia enam bulan. Pada mereka tetap diberikan air gula sebagai pendamping ASI atau ditambah susu formula, supaya bayi tidak menangis karena lapar.

Sedangkan pada etnik Madura bayi tidak hanya minum ASI, tetapi setiap pagi dan sore disuapi pisang yang dicampur dengan nasi tim, sebelum usia enam bulan. Untuk menyuapkan makanan bagi bayi ada dua cara yaitu dengan menggunakan sendok dan menggunakan cara tradisional, yaitu bayi diikat di atas kaki penyuap yang sedang berselonjor, kemudian disuapi dengan tangan tanpa memperdulikan bayi yang menangis meronta. Masyarakat berpikir bahwa cara ini dilakukan untuk membuat bayi kenyang, bukan bermaksud untuk menyakiti bayi.

\section{Frekuensi Pemberian ASI}

Para ibu etnik Rote tidak menentukan waktu menyusui bayi mereka. Setiap saat bayi membutuhkan ASI, para ibu tersebut memberikan ASI mereka. Frekuensi pemberian ASI relatif lebih banyak. Meskipun ibu tahu persis bahwa bayinya tidak lapar, tapi pada kondisi tertentu, misalnya: menangis atau rewel, ibu langsung menyusui bayi mereka.

Pada etnik Sabu air sari daun cabai/lombok "ro' hili" diberikan sebelum bayi menerima ASI sebanyak tiga kali dalam sehari, selama lima hari. Setelah air susu ibu keluar, air gula diberikan secara bergantian. Tidak ada frekuensi waktu menyusui bayi, karena setiap saat akan di berikan ASI. Sedangkan untuk air gula diberikan sehari tiga kali selama 5 hari kepada bayi dan balita. Sudah menjadi tradisi sejak bayi hingga anak balita mengonsumsi air gula sabu setiap akan tidur.

Frekuensi menyusui bayi pada etnik Madura adalah sesering mungkin. Jika bayi menangis karena merasa lapar, maka ibu akan segera menyusui bayinya. Ibu menyusui bayinya tidak peduli siang atau malam, tetap menyusui bayinya. Masih ada beberapa ibu memberikan susu formula, bahkan pada saat bayi masih berusia kurang dari 7 hari. Ibu merasa bahwa ASI-nya kurang mencukupi dan bayi masih lapar.

\section{Asupan Makanan Bagi Ibu Menyusui}

Makanan sehari-hari pada masyarakat Desa Limokali pada etnik Rote berupa sayuran, meskipun jenisnya kurang beragam. Sayuran yang biasa dikonsumsi bagi ibu menyusui merupakan jenis sayur yang biasa ditanam di kebun setempat seperti 
kangkung, bayam, dan sawi. Selain itu sumber sayuran untuk dimakan juga berasal dari halaman rumah setempat seperti sayur daun marungga, sayur pucuk daun labu, dan sayur bunga pepaya. Sedangkan konsumsi buah sangat kurang. Hal ini disebabkan keterbatasan jenis buah yang ada di Desa Limokali. Jenis buah yang tumbuh antara lain buah pisang dan buah pepaya. Tetapi dua jenis buah ini jarang di konsumsi, karena penduduk setempat lebih memilih untuk menjual dibandingkan untuk mengkonsumsinya. Ibu menyusui biasa mengonsumsi kacang tanah, sepotong daging ayam atau sepotong daging sapi. Daging tersebut diolah dengan cara digoreng, direbus, atau dipanggang tanpa menggunakan bumbu masak dan garam.

Pada masyarakat etnik Sabu, khususnya ibu menyusui, setiap pagi sarapan dengan segelas air gula dan sepiring bubur. Bubur terbuat dari beras atau kacang hijau atau kacang merah. Makan siang dan makan malam serta makanan selingan ibu menyusui adalah nasi putih sepiring dengan sepotong ikan laut yang sudah dikeringkan. Untuk makan ikan, kepala keluarga harus pergi ke laut mencari ikan. Ikan atau gurita tersebut dikeringkan dengan cara dijemur di bawah sinar matahari agar awet dan tahan lama. Sedangkan makanan pokok masyarakat Desa Kolorae adalah sorgum atau sejenis gandum. Untuk sayur dan buah memang sulit ditemukan di daerah ini. Sayuran dan buah tertentu seperti daun papaya dan labu kuning adalah menu keseharian yang dikonsumsi. Sayur bayam dan kangkung hanya bisa ditemukan pada saat musim hujan. Sedangkan buah jarang ditemukan kecuali buah kelapa.

Pada etnik Madura makanan yang dikonsumsi bagi ibu menyusui sehari hari berupa nasi, ikan asin, serta kacang-kacangan yang merupakan makanan selingan serta minum ramuan tradisional. Sedangkan buah dan sayuran kurang disukai.

\section{Pantangan Ibu Selama Menyusui}

Pada etnik Rote ibu yang menyusui berupaya memelihara agar ASI tetap cukup dan berkualitas antara lain dengan mengonsumsi jenis kacang-kacangan dan sayur daun marungga. Sedangkan pantangan yang tidak boleh di konsumsi adalah makanan yang pedas karena dapat menyebabkan sakit perut pada bayi dan tidak boleh mengonsumsi daging babi karena menyebabkan perut bayi menjadi kembung. Meskipun secara medis tidak seluruhnya terbukti, namun ada upaya yang dengan sengaja dilakukan oleh para ibu etnik Rote untuk memelihara dan meningkatkan kualitas ASI. Paling tidak hal tersebut tidak bertentangan dengan kesehatan bayi.

Berbeda dengan masyarakat pada etnik Rote, maka pada etnik Sabu tidak ada pantangan ibu selama menyusui. Mereka beranggapan air gula sabu yang diminumkan untuk ibu menyusui dan bayinya sangat bermanfaat buat kesehatan selain membuat kenyang juga dapat mencegah sakit perut pada bayi. Selain itu air gula sabu juga bermanfaat pada saat bayi baru lahir.

Pada etnik Madura ada beberapa pantangan untuk ibu ketika sedang dalam masa menyusui bayi, di antaranya adalah ibu tidak diperkenankan mengonsumsi ikan laut karena dikhawatirkan ASI-nya akan berbau amis. Selain itu, ibu juga tidak boleh mengonsumsi cabai terlalu banyak karena ASI akan terasa pedas dan menyebabkan mata bayi kotor serta merah. Untuk pantangan selain makanan, si ibu tidak boleh terlalu sering melakukan hubungan seksual agar ASI tidak panas sehingga bayi kurang menyukainya. Berikut pernyataan informan tentang pantangan makanan saat menyusui, "..tidak boleh makan ikan karena membuat ASI amis. Kalau cabai juga tidak boleh karena nanti mata bayi bisa kotor, bu..”.

\section{PEMBAHASAN}

Perilaku pemberian ASI guna proses tumbuh kembang bayi, juga memberikan manfaat untuk mencegah bayi dari sakit. Masa menyusui dimulai sejak bayi keluar dari rahim ibu hingga bayi berumur dua tahun. Sejak bayi baru lahir sampai berumur dua tahun hanya diberikan ASI tanpa makanan tambahan apapun kecuali vitamin, mineral atau obat dalam bentuk tetes atau sirup hingga enam bulan. Kemampuan ibu dalam menyusui dengan teknik yang benar sangat mendukung perilaku ibu dalam memberikan ASI kepada bayinya. Teknik menyusui dengan benar akan mempengaruhi pemberian ASI pada bayi. Penelitian Rhokliana, dkk. (2011), menunjukkan ada hubungan antara kondisi sosial budaya masyarakat dengan keberhasilan ibu dalam menyusui bayinya. Kegagalan ibu pada saat memberikan ASI kepada bayinya disebabkan faktor ketidaktahuan ibu tentang cara menyusui dengan benar. Sedangkan pengeluaran ASI bisa lancar, karena ibu menyusui juga melakukan perawatan payudara ibu post partum. Penelitian ini sejalan dengan hasil penelitian Scholichah (2012), yang 
menunjukkan adanya hubungan antara perawatan payudara pada ibu post partum dengan kelancaran pengeluaran ASI.

\section{Pemberian ASI Eksklusif}

Pada etnik Rote sebagian besar ibu menyusui masih membuang kolostrum dengan alasan air susu tersebut terlalu kental. Hasil penelitian Marizka K, dkk (2014) menyebutkan bahwa program ASI eksklusif yang dicanangkan oleh pemerintah di Desa Limokali, Kabupaten Rote Ndao khususnya etnik Rote ini belum dapat tercapai. Para ibu pada etnik Sabu dan etnik Madura juga masih membuang kolostrum dengan alasan kolostrum adalah ASI yang kotor. Padahal bidan di posyandu telah melakukan penyuluhan kesehatan tentang ASI dan manfaat kolostrum (Dahlianti, Nasoetion dan Roosita, 2005). Jadi memang ada alasan yang biasanya berkaitan dengan budaya setempat dalam hubungannya dengan pemberian ASI eksklusif (Yusrina \& Devy, 2016).

Pengetahuan masyarakat di beberapa etnik di Indonesia masih menganggap bahwa ASI yang pertama kali keluar basi, sehingga mereka membuang ASI tersebut. Hal ini bertentangan dengan Kepmenkes No 450/Menkes/SK/VI/2004 tentang pemberian ASI secara eksklusif di Indonesia selama bayi 6 bulan. Menurut UU No 36/2009 tentang Kesehatan pasal 129 (1) pemerintah bertanggung jawab menetapkan kebijakan dalam rangka menjamin hak bayi untuk mendapatkan air susu ibu secara eksklusif. Keputusan WHO juga mengharuskan pemberian ASI eksklusif hingga bayi berusia 6 bulan karena pencernaan bayi belum mampu menerima makanan lain selain ASI. Secara tidak langsung pemberian kolostrum pada bayi memiliki dampak terhadap status gizi balita (Masithah, dkk, 2005). Bayi yang tidak memperoleh kolostrum akan memiliki kekebalan tubuh kurang, jika dibandingkan bayi yang diberi kolostrum.

Berbagai macam hal yang dapat mempengaruhi produksi ASI adalah tidak melakukan inisiasi menyusui dini, ibu menjadwalkan sendiri pemberian ASI, bayi diberi minum sebelum air susu ibu keluar, dan posisi menyusui ibu yang kurang baik. Ibu menyusui harus memperhatikan hal-hal tersebut. Ada kalanya ibu beranggapan bahwa produksi ASI tidak mencukupi sehingga memutuskan untuk menambahkan atau mengganti dengan susu formula.

\section{Pemberian Minuman Bayi Baru Lahir}

Para ibu pada etnik Rote di Desa Limakoli memberikan seduhan air kopi atau air gula pada bayinya yang baru lahir, begitu pula para ibu pada etnik Sabu Desa Kolorae. Tujuan pemberian air gula tersebut adalah agar bayinya kuat dan kenyang. Air gula tersebut disukai bayi karena rasa manisnya.

Pada etnik Madura, bayi baru lahir diberi madu dan air kelapa muda. Minuman prelakteal ini berbahaya karena dianggap sebagai pengganti kolostrum, sehingga diberikan sebagai minuman bayi paling awal. Pemberian minuman prelakteal pada bayi baru lahir sangat merugikan karena akan menghilangkan rasa haus bayi, sehingga bayi malas menyusui. Minuman prelakteal yang terbanyak diberikan di Indonesia adalah susu formula, secara nasional sebesar 79,8\% (Riskesdas, 2013).

\section{Pemberian Makanan Pendamping ASI}

Makanan Pendamping ASI (MP-ASI) merupakan makanan yang diberikan pada bayi untuk memenuhi kebutuhan gizi di samping ASI dan mulai diberikan saat bayi berusia enam bulan. Sebelum bayi berusia enam bulan, enzim pencernaan dan system kekebalan usus bayi belum sempurna sehingga zat tepung dan protein belum dapat dicerna oleh bayi (Najahah dkk., 2013). Makanan pendamping ASI ini berupa pisang halus, atau produk bubur instan. Pilihan makanan yang tepat untuk bayi, menyebabkan bayi terhindar dari kekurangan gizi dan bayi tidak sering menderita penyakit (Masaora, 2003).

Pada etnik Rote, makanan pendamping ASI berupa bubur nasi atau bubur dari beras yang dibuat sendiri oleh ibu dan juga bubur susu instan. Pada etnik Sabu dan etnik Madura, setiap pagi dan sore bayi disuapi pisang yang dihaluskan dan dicampur dengan nasi tim. Namun pemberian makanan pendamping ASI pada etnik ini sebagian besar diberikan sebelum bayi berusia 6 bulan. Mereka beralasan agar bayi tidak rewel. Hasil penelitian (Rizki K I \& Lailatul M, 2016) di Desa Ujung Piring Bangkalan, Madura menyatakan bahwa pemberian MP-ASI secara dini kepada bayi sebelum berusia 6 bulan adalah sebesar $35,5 \%$ berupa pisang di haluskan serta bubur susu instant.

\section{Frekuensi Pemberian ASI}

Indikator keberhasilan menyusui diukur dari frekuensi, durasi Air Susu Ibu (ASI), pertumbuhan bayi, dan status gizi ibu pasca menyusui (Fikawati dkk, 2015). Kebutuhan kalori bagi ibu menyusui sebanyak 500-1000 kalori lebih banyak dari ibu yang tidak menyusui. Pada ibu menyusui sering kekurangan magnesium, vitamin B6, folat, kalsium 
dan seng. Sedangkan nutrisi yang tidak adekuat pada ibu menyusui dapat menurunkan jumlah produksi Air Susu Ibu (ASI) (Proverawati \& Rahmawati, 2010). Pada etnik Rote, etnik Sabu dan etnik Madura tidak ada frekuensi waktu mereka menyusui. Mereka menyusui sesering mungkin bahkan tidak ditentukan waktunya. Menurut Suradi R, dkk (2010), agar ASI dapat diproduksi dengan jumlah dan kualitas yang baik maka diperlukan asupan gizi ibu menyusui mencukupi, teknik cara menyusui yang benar, dan seringnya frekuensi menyusui. Semakin sering bayi menyusu kepada ibunya, maka produksi ASI akan lancar.

\section{Asupan Makanan Bagi Ibu Menyusui}

Pada ibu menyusui kebutuhan gizi meningkat dibandingkan dengan tidak menyusui dan masa kehamilan (Kemenkes RI, 2014). Gizi ibu menyusui dalam enam bulan pertama membutuhkan tambahan energi sebesar 500 kalori per hari untuk menghasilkan jumlah susu normal. Total kebutuhan energi selama menyusui meningkat menjadi 2400 kal per hari yang digunakan untuk memproduksi ASI dan aktivitas ibu. Pelaksanaan gizi seimbang yang dianjurkan dapat dibagi menjadi enam kali makan (tiga kali makan utama dan tiga kali makan selingan). Selain itu, ibu menyusui sangat membutuhkan cairan agar dapat menghasilkan air susu dengan cepat. Dianjurkan minum air lebih dari delapan gelas sehari.

Ibu menyusui dengan gizi buruk akan mempengaruhi kecukupan ASI, karena tubuh membutuhkan zat gizi yang cukup untuk memproduksi ASI. Ada hubungan antara status gizi ibu menyusui dengan kecukupan ASI (Nurul. P, 2010). Beberapa etnik di Indonesia, khususnya pada etnik Rote, ibu menyusui makan perhari berupa nasi, sayur dan ikan, namun jumlah porsi per harinya tidak dijelaskan. Sedangkan buah dan susu jarang dikonsumsi. Pada etnik Sabu asupan perhari rata-rata hanya makan nasi atau bubur dan sepotong ikan kering tetapi juga tidak menjelaskan ukuran porsinya per hari. Sedangkan sayur dan buah jarang dikonsumsi, karena jarang ditemukan, apalagi susu. Pada etnik Madura asupan makanan bagi ibu menyusui per hari yaitu nasi, ikan asin dan selingan berupa kacang-kacangan, namun tidak dijelaskan jumlah porsinya per hari. Sayur dan buah dikonsumsi, namun tidak setiap hari. Minum jamu tradisional dikonsumsi setiap hari sedangkan susu jarang dikonsumsi oleh ibu menyusui. Menurut hasil penelitian (Ni Kadek R, dkk, 2017) ada hubungan antara pemenuhan kebutuhan gizi ibu dengan kelancaran ASI pada ibu menyusui di Puskesmas Bahu Kota Manado. Sedangkan hasil penelitian (Irma Eva Yani, dkk, 2009) menyebutkan bahwa ibu tidak memberikan ASI pada bayinya $(54,6 \%)$ dikarenakan tidak tersedianya makanan dirumah. Tidak adanya makanan yang dikonsumsi ibu sehingga menyebabkan ibu tidak memberikan ASI pada bayinya.

Tingkat pendidikan ibu menyusui juga dapat berpengaruh pada pengetahuan ibu. Pada ibu-ibu yang memiliki tingkat pengetahuan yang cukup, maka ibu dapat memilih pengolahan dan pengaturan makanan sehari-hari. Hal tersebut menyebutkan ibu menyusui dapat mengonsumsi makanannya dengan gizi yang seimbang setiap hari (Maharani, 2016).

\section{Pantangan Ibu Selama Menyusui}

Hasil penelitian (Rizki K I dan Lailatul M, 2016) saat menyusui adanya pantangan makan tertentu bagi

Tabel 1. Pengaturan Jumlah Porsi Makan Utama dan Makan Selingan dalam Sehari Ibu Menyusui

\begin{tabular}{|c|c|c|c|c|c|c|c|}
\hline \multirow[b]{2}{*}{ Bahan Makanan/ Penukar } & \multirow{2}{*}{$\begin{array}{c}\text { Jumlah } \\
\text { Porsi }\end{array}$} & \multicolumn{6}{|c|}{2.400 kkal } \\
\hline & & Pagi & $\begin{array}{c}\text { Selingan } \\
\text { pagi }\end{array}$ & Siang & $\begin{array}{l}\text { Selingan } \\
\text { sore }\end{array}$ & Malam & $\begin{array}{c}\text { Selingan } \\
\text { malam }\end{array}$ \\
\hline Nasi/ Karbohidrat & $11 / 2$ & $1 / 2$ & $1 / 2$ & $11 / 2$ & $1 / 2$ & 2 & - \\
\hline Daging/ Lauk hewani & 3 & 1 & - & 1 & - & 1 & - \\
\hline Tempe/ Lauk nabati & $31 / 2$ & 1 & - & 1 & $1 / 2$ & 1 & - \\
\hline Sayuran & $31 / 2$ & $11 / 4$ & - & $11 / 4$ & - & 1 & - \\
\hline Buah & 5 & 1 & 1 & 1 & - & 1 & 1 \\
\hline Minnyak/ lemak & 6 & 1 & 1 & 1 & 1 & 2 & - \\
\hline Susu & 1 & - & - & - & - & - & 1 \\
\hline Gula & 2 & $1 / 2$ & 1 & - & - & - & 1 \\
\hline
\end{tabular}

Sumber: Kurniash, dkk, 201 
ibu pada etnik Madura yaitu pantangan makan ikan laut sebesar 4,8\% karena dikhawatirkan air susu ibu menjadi amis dan pantangan makan cabai sebesar $64,5 \%$ dikhawatirkan bayi menjadi diare. Pantangan makan tertentu bagi ibu menyusui pada etnik Rote dan Madura hampir sama. Hal ini tidak tepat karena ikan mengandung protein yang diperlukan untuk pertumbuhan bayi dan tidak berpengaruh terhadap rasa ASI. Pembatasan makanan pada ibu menyusui menyebabkan nutrisi ibu menyusui kurang terpenuhi. Kebiasaan seperti diatas dianggap mitos sehingga perlu diubah secara bertahap dan sistematis melalui pendekatan yang tepat. Kurangnya asupan gizi ibu menyusui mempengaruhi kesehatan dan produksi air susu ibu (Kristiyansari, 2009).

\section{KESIMPULAN DAN SARAN}

\section{Kesimpulan}

Perilaku ibu menyusui pada etnik Rote, etnik Sabu dan etnik Madura pada masa menyusui sebagian besar memberikan makanan atau minuman sebelum bayi berusia enam bulan. Tindakan tersebut dilakukan dengan alasan supaya bayi tidak rewel dan tidak menangis. Beberapa pantangan makanan bagi ibu selama menyusui bertujuan supaya bayinya tidak sakit-sakitan. Perilaku ibu menyusui tidak membatasi frekuensi untuk menyusui dan sesering mungkin bahkan tidak menentukan waktu, setiap saat memberikan ASI bagi bayinya, hal ini membuat bayinya terlindungi serta diperhatikan oleh ibunya setiap saat. Pemenuhan gizi pada ibu menyusui pada etnik Rote, etnik Sabu dan etnik Madura belum sesuai dengan anjuran Kementerian Kesehatan dalam memenuhi kecukupan gizinya, karena tidak dijelaskan porsinya per hari.

\section{Saran}

Perlu penyuluhan dengan melibatkan lintas sektor seperti dinas kesehatan, puskesmas, dan perangkat desa untuk mengubah perilaku dan persepsi masyarakat tentang kepercayaan dan tradisi yang terkait pemberian ASI eksklusif. Perlu memberikan penyuluhan dengan melibatkan orang tua dari ibu balita serta tokoh masyarakat dalam penyuluhan kesehatan agar mengurangi pemberian makanan/ minuman prelakteal pada bayi baru lahir, asupan gizi ibu menyusui yang cukup, pemberian makanan pendamping ASI sebelum 6 bulan serta upaya mengubah kepercayaan pantang makanan tertentu pada ibu menyusui. Diharapkan pemerintah daerah mengadakan program kesehatan untuk Pemberian Makanan Tambahan Pemulihan (PMT-P) berupa susu dan lainnya untuk pemulihan kondisi yang mempengaruhi penurunan status gizi pada ibu hamil dan menyusui yang disebabkan adanya budaya turun temurun warga berupa pantangan dalam memberikan sayur dan buah pada masa kehamilan ibu.

\section{UCAPAN TERIMA KASIH}

Penulis mengucapkan terima kasih kepada Kepala Badan Penelitian dan Pengembangan Kesehatan, Kepala Puslitbang Humaniora dan Manajemen Kesehatan, dan semua pihak yang telah berkontribusi dalam artikel ini.

\section{DAFTAR PUSTAKA}

Anur Rohmin, Nura Malahayati, Hartati, 2015. Faktor-Faktor yang Mempengaruhi Praktek

Pemberian Makanan Prelakteal Pada Bayi Baru Lahir di Kecamatan Bukit Kecil Kota

Palembang. Jurnal Kesehatan Volume IV, Nomor 2, Oktober 2015, Hal 183-19.

Arisman, M.B. 2007. Gizi Dalam Daur Kehidupan. Jakarta: EGC.

Badan Litbangkes Kemenkes RI, 2013. Riset Kesehatan Dasar Tahun 2013. Jakarta.

Dahlianti R, Nasoetion, A, Roosita K, 2005. Keragaan Perawatan Kesehatan Masa nifas, Pola

Konsumsi Jamu Tradisional dan Pengaruhnya Pada Ibu Nifas di Desa Sukajadi,

Kecamatan Tamansari, Kabupaten Bogor. Jurnal Media dan Gizi Keluarga. 29 (2), 55-65.

Fikawati dkk, 2015. Gizi Ibu dan Bayi. Jakarta: PT RajaGrafindo Persada.

Firman Edu, 2015. Aspek Sosial Budaya dalam Kesehatan. https://firmanedu.wordpress.com/2015/03/page/2

Kemenkes RI, 2011.Makanan Sehat Ibu Menyusui. Direktorat Bina Kesehatan Masyarakat.Jakarta

Kementerian Kesehatan RI, 2014. Pedoman Gizi Seimbang. Kementerian Kesehatan RI: Direktorat Bina Gizi

Kristiyansari, W, 2009. ASI, Menyusui dan Sadari. Yogyakarta: Muha Medika.

Kurniasih, D, Hilmansyah, H, Astuti, MP, Imam,S, 2010. Sehat \& Bugar Berkat Gizi Seimbang. Jakarta: PT Penelitian Sarana Bobo.

Hamzah, Asiah, 2000. Pola Asuh Anak Pada Etnik Jawa Migran dan Etnik Mandar. Disertasi, Program Pascasarjana Univ. Airlangga, Surabaya.

Irma Eva Yani, Defriani Dwiyanti, Novelasari, 2009. FaktorFaktor yang Mempengaruhi 
Perilaku Ibu Laktasi Dalam Memberikan ASI di Kab/Kota Provinsi Sumbar. Jurnal Penelitian Gizi Makan (PGM) 32 (2): 101-111.

Masoara, S. 2003. Manfaat ASI untuk bayi, ibu dan keluarga. Program Manajemen Laktasi,Jakarta: Perkumpulan Perinatologi Indonesia. Marizka K, Indah Nur Esti Leksana, Dusri L.M, Betty Roosihermiatie, 2014. Perempuan Rote Meniti Tradisi, Etnik Rote, Kabupaten Rote

Ndao, Provinsi NTT. Buku Seri Etnografi Kesehatan 2014. Jakarta: Lembaga Penerbitan BalitbangkesKemenkes RI

Maharani, 2016. Faktor-Faktor yang berhubungan dengan Status Gizi Ibu Menyusui di Wilayah Kerja Puskesmas Kedungmundu Kota Semarang. Jurnal FKM Universitas Diponegoro Semarang. Diakses pada tanggal 04 Desember 2017

Najahah I, KT Adhi, GNI Pinatih, 2013. Faktor Risiko Balita Stunting Usia 12-36 Bulan di Puskesmas Dasan Agung Mataram, Provinsi Nusa Tenggara Barat. Public Health and Preventiv Medicine Archive 1 (2), 134-141. Diakses dari: http://download.portalgaruda. org/article

Nurul Pujiastuti, 2010. Korelasi Antara Status Gizi Ibu Menyusui Dengan Kecukupan ASI di Posyandu Desa Karang Kedawang Kecamatan Sooko Kabupaten Mojokerto. Jurnal Keperawatan. Vol 1 no 2 Juli:126137 ISSN: 2086-3071

Ni Kadek Radharisnawati, Rina Kundre, Linnie Pondaag, 2017. Hubungan Pemenuhan

Kebutuhan Gizi dengan Kelancaran Air Susu Ibu (ASI) Pada Ibu Menyusui di Puskesmas Bahu Kota Manado. E-Journal Keperawatan (e-Kp), Vol 5. No 1.

Ratna Widyasari, Ida Diana Sari, Aprilliana Lailatul M, Sofyan Haryanto, M. Setyo Pramono, 2012. Etnik Madura Desa Jrangon Kecamatan Omben Kabupaten Sampang, Provinsi Jawa Timur. Buku Seri Etnografi Kesehatan 2012. Jakarta: Lembaga Penerbitan Balitbangkes-Kemenkes RI
Rhokliana, Aisyah.S, Chandradewi, A.A.S.P. 2011. Hubungan Sosial Budaya dengan Pemberian ASI pada Bayi di Wilayah Kerja Puskesmas Kruak Kabupaten Nusa Lombok Timur, Jurnal Kesehatan Prima [e-journal]5(2):pp 765-777

Rizki Kurnia Illahi, Lailatul Muniroh, 2016. Gambaran Sosio Budaya Gizi Etnik Madura dan Kejadian Stunting Balita Usia 24-59 bulan di Bangkalan Madura. Media Gizi Indonesia, Vol 11, No.2 Juli-Desember: hlm 135-143.

Rukiyah, Ai Yeyeh, Lia Yulianti, Meida Liana, 2010. Asuhan Kebidanan III (Nifas). CV. Trans Info Media: Jakarta Timur.

Roland A.N, Indriyaningsih, Agung Dwi L. 2015. Daun Ro Hili \& Air Gula Sabu, Penyambut Bayi Baru Lahir, Etnik Sabu, Kabupaten Sabu Raijua. Buku Seri Etnografi Kesehatan 2015. Jakarta: Lembaga Penerbitan Balitbangkes-Kemenkes RI

Proverawati \& Rahmawati, 2010. Kapita Selekta Asi \& Menyusui. Yogyakarta: Nuha Medika

WHO, 2013. Breas-feeding-Exclusive Breasfeeding. Tersedia dari http://www.who.int/elena/titles/ exclusive_breastfeeding/en/index.html.

World Health Organization. 2016. Breastfeeding: Only 1 in 5 Countries Fully Implement

WHO's Infant Formula Code. Diakses: 18 April 2016. http://www.who.int/mediacentre/news/releases/2013/ world_breastfeeding_week_20130730/en

Scholichah N . 2012. Hubungan Perawatan Payudara pada Ibu Postpartum dengan Kelancaran Pengeluaran ASI di Desa Karang Duren Kecamatan Tengaran Kabupaten Semarang. Jurnal Komunikasi Kesehatan (Edisi 3), 2(02):1-7, 2012

Suradi R, Hegar B, Partiwi IGAN, Marzuki ANS, Ananta Y, 2010. Indonesia Menyusui. Jakarta: Badan Penerbit IDAI.

Yusrina, A, Devy, S.R.2016. Faktor yang Mempengaruhi Niat Ibu Memberikan ASI Eksklusif di Kelurahan Magersari, Sidoarjo. Journal Promosi dan Pendidikan Kesehatan Indonesia. [e- journal] (1):pp.11-12. 